\title{
Present and New Treatment Strategies in the Management of Glaucoma
}

\author{
M. Kolko *,1,2,3 \\ ${ }^{I}$ Department of Neuroscience and Pharmacology, the Panum Institute, University of Copenhagen, Denmark \\ ${ }^{2}$ Department of Ophthalmology, Roskilde University Hospital, Copenhagen, Denmark \\ ${ }^{3}$ Center of Healthy Aging, Department of Cellular and Molecular Medicine, the Panum Institute, University of \\ Copenhagen, Denmark
}

\begin{abstract}
Glaucoma is a neurodegenerative disease characterized by retinal ganglion cell (RGC) death and axonal loss. It remains a major cause of blindness worldwide. All current modalities of treatment are focused on lowering intraocular pressure (IOP), and it is evident that increased IOP is an important risk factor for progression of the disease. However, it is clear that a significant number of glaucoma patients show disease progression despite of pressure lowering treatments. Much attention has been given to the development of neuroprotective treatment strategies, but the identification of such has been hampered by lack of understanding of the etiology of glaucoma. Hence, in spite of many attempts no neuroprotective drug has yet been clinically approved. Even though neuroprotection is without doubt an important treatment strategy, many glaucoma subjects are diagnosed after substantial loss of RGCs. In this matter, recent approaches aim to rescue RGCs and regenerate axons in order to restore visual function in glaucoma. The present review seeks to provide an overview of the present and new treatment strategies in the management of glaucoma. The treatment strategies are divided into current available glaucoma medications, new pressure lowering targets, prospective neuroprotective interventions, and finally possible neuroregenrative strategies.
\end{abstract}

Keywords: Glaucoma, intraocular pressure lowering drugs, neuroprotection, neuroregeneration, treatment strategies.

\section{INTRODUCTION}

Glaucoma refers to a group of eye conditions, which cause progressive damage to the optic nerve, retinal ganglion cell (RGC) death, and characteristic damage to the visual field. According to The World Health Organization, glaucoma accounted for 2 percent of visual impairment and 8 percent of global blindness in 2010, and the number of glaucoma patients is estimated to increase due to a growing population [1]. The classification of glaucoma relies on the appearance and obstruction of the drainage pathway. In open angle glaucoma (OAG) the drainage pathway appears normal and in angle-closure glaucoma (ACG) the drainage pathway is obstructed. Glaucoma is also classified according to whether it is primary or associated with detectable comorbidity, secondary glaucoma. The most common subtype of glaucoma is primary OAG (POAG). Despite the normal clinical appearance of the drainage pathway the aqueous outflow is restricted in most POAG and referred to as high-tension glaucoma (HTG). Hence, glaucoma is associated with an increase in intraocular pressure (IOP), and to date IOP lowering drugs remain the only clinically validated treatment of glaucoma [2]. Despite the significant importance of IOP in the risk of glaucoma progression, it is recognized that elevated IOP appears in the absence of the characteristic optic nerve changes (ocular hypertension

*Address correspondence to this author at the Department of Neuroscience and Pharmacology, University of Copenhagen, Blegdamsvej 3b, 2200 Copenhagen, Denmark; Tel: 0045 29807667;

E-mail: mkolko@dadlnet.dk
(OHT) ) and conversely glaucomatous optic nerve damage appears in the absence of an elevated IOP (low-tension glaucoma (LTG)).

Therefore, despite the fact that IOP lowering interventions reduce the risk of progression and delay the disease onset of glaucoma, the pathogenesis is controversial and not completely understood. In this matter non-IOPdependent risk factors appear to be responsible for approximately 30-70 percent of glaucoma cases [3-6].

The present review seeks to 1) briefly summarize the current treatment strategies for glaucoma, 2) discuss future treatment strategies for glaucoma i.e. new targets for IOPlowering, targets for neuroprotection, and targets for neuroregeneration.

\section{CURRENT TREATMENT STRATEGIES FOR GLAUCOMA}

Although glaucoma is a complex and poorly understood disorder, the primary goal of therapy is lowering IOP [2]. Hence, lowering IOP by 20 - 40 percent has been shown to reduce the rate of progressive visual field loss by half $[7,8]$.

The first anti-glaucomatous drop was introduced in 1875 and there are currently several types of IOP-lowering eye drops used to treat glaucoma (Table 1). In addition, two systemic IOP-lowering drugs are available (Table 2). The eye drops include $\beta$-blockers, carbonic anhydrase inhibitors, prostaglandin analogs, $\alpha 2$-adrenergic agonists, and parasympathomimetic drugs. In addition to the pure form, 
the eye-drops often come as combined drops. To date fixedcombination eye-drops include prostaglandin analogs $/ \beta$ blockers, carbonic anhydrase inhibitors/ $\beta$-blockers, and $\alpha 2$ adrenergic agonists $/ \beta$-blockers. Finally, a combination of carbonic anhydrase inhibitors $/ \alpha 2$-adrenergic agonists was approved by the United States Food and Drug Administration in April 2013, and as an exception a triple fixed combination of prostaglandin analogs/ $\alpha 2$-adrenergic agonists/ $\beta$-blockers is available in Mexico.

Table 1. Time line for the introduction of glaucoma medication.

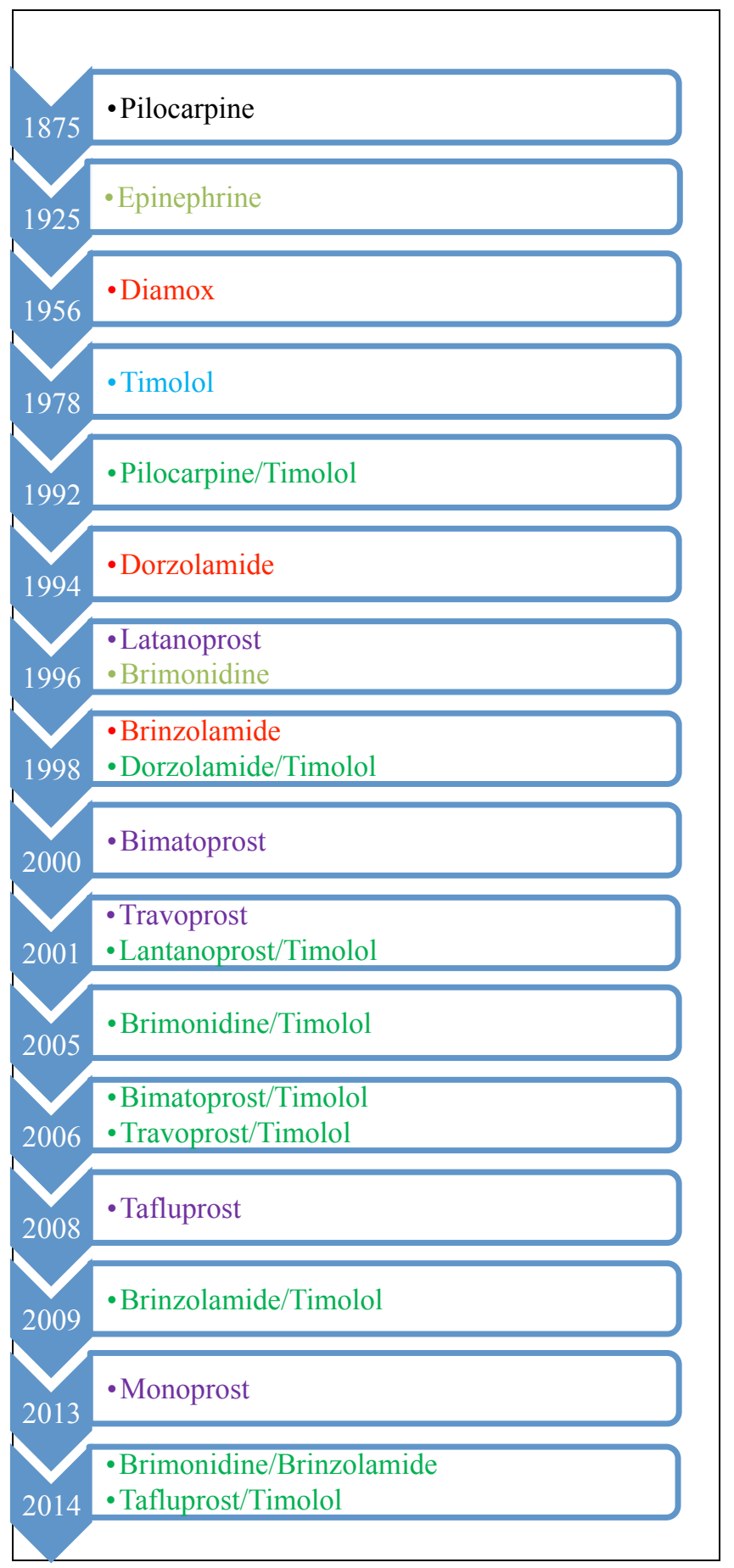

IOP Lowering medication and year of introduction. Modified from European Glaucoma Society Therminology and Guidelines for Glaucoma, $4^{\text {th }}$ edition.
Over all, the current available glaucoma eye-drops all seek to decrease the IOP. They can be grouped into therapeutic agents that decrease the production of aqueous humor production and/or increase the drainage through the trabecular meshwork (TM) and/or increase uveoscleral outflow.

\section{B-Blockers}

B-blockers reduce the production of aqueous humor. In addition, some $\beta$-blockers contain $\alpha 1$ blocking effects (levobunolol and nipradilol) [9-11], which reduce IOP by an acceleration of the uveoscleral outflow. Ocular adverse reactions include conjunctival allergies, conjunctival injection and corneal epithelium disorder. Additionally, corneal sensitivity may be reduced in case of the selective B1-blocker, betaxolol, due to its membrane-stabilizing effect. In contrast, another ß-blocker, carteolol, has intrinsic sympathomimetic activity and therefore no reduced corneal sensitivity [12]. One major challenge for the use of $\beta$-blockers is their frequent systemic adverse effect due to their activation of both $B 1$ - and $B 2$-receptors. In this matter adverse effects of the respiratory system by ß2-blockers include worsening of asthma attacks and chronic obstructive pulmonary disease. To prevent the 32 -related side effects betaxolol can be used in cases with respiratory issues [13]. The most critical adverse effects of $\beta 1$-blockage are reduced heart rate and reduced cardiac contractility. Hence, B-blockers should be used with caution in patients with slow or irregular heartbeat or congestive heart failure. Finally, adverse effects from the use of $\beta$-blockers include depression, impotence, and drowsiness.

\section{Carbonic Anhydrase Inhibitors}

Carbonic anhydrase inhibitor (CAI)s reduce IOP by inhibiting the ciliary epithelium and controlling aqueous formation. Systemic CAIs have been used since 1956, but are associated with a high incidence of adverse reactions, including dysesthesia of the fingers and around the lips, frequent urination, lassitude, anorexia, weight reduction, kidney stones, metabolic acidosis, and hematopoietic cell restraint anemia [14]. Since 1994 a topical CAI has been available (Table 1). Even though the adverse effects are much less compared to systemic administered CAIs, topical CAIs have some ocular adverse reactions such as conjunctival allergy and hyperemia [14]. Due to the fairly acidic $\mathrm{pH}$, CAIs generally cause ocular irritation. Moreover, carbon anhydrase naturally exists in the endothelial cells, and CAIs should be used with caution in patients with corneal endothelial disorders [15]. No significant systemic adverse reactions have been associated with the use of CAIs.

\section{Prostaglandin Analogs}

Prostaglandins lower IOP by accelerating the uveoscleral outflow. The most common adverse effects are eye redness or irritation, a change in eye color (mostly in hazel or green eyes) $[16,17]$, and an increase in thickness and number of eyelashes [18]. In addition, prostaglandin administration has been reported to recur corneal epithelium herpes, and should therefore be used with caution in these patients [19]. No significant systemic adverse reactions have been associated with the use of prostaglandins. 
Table 2 Current treatment strategies for glaucoma.

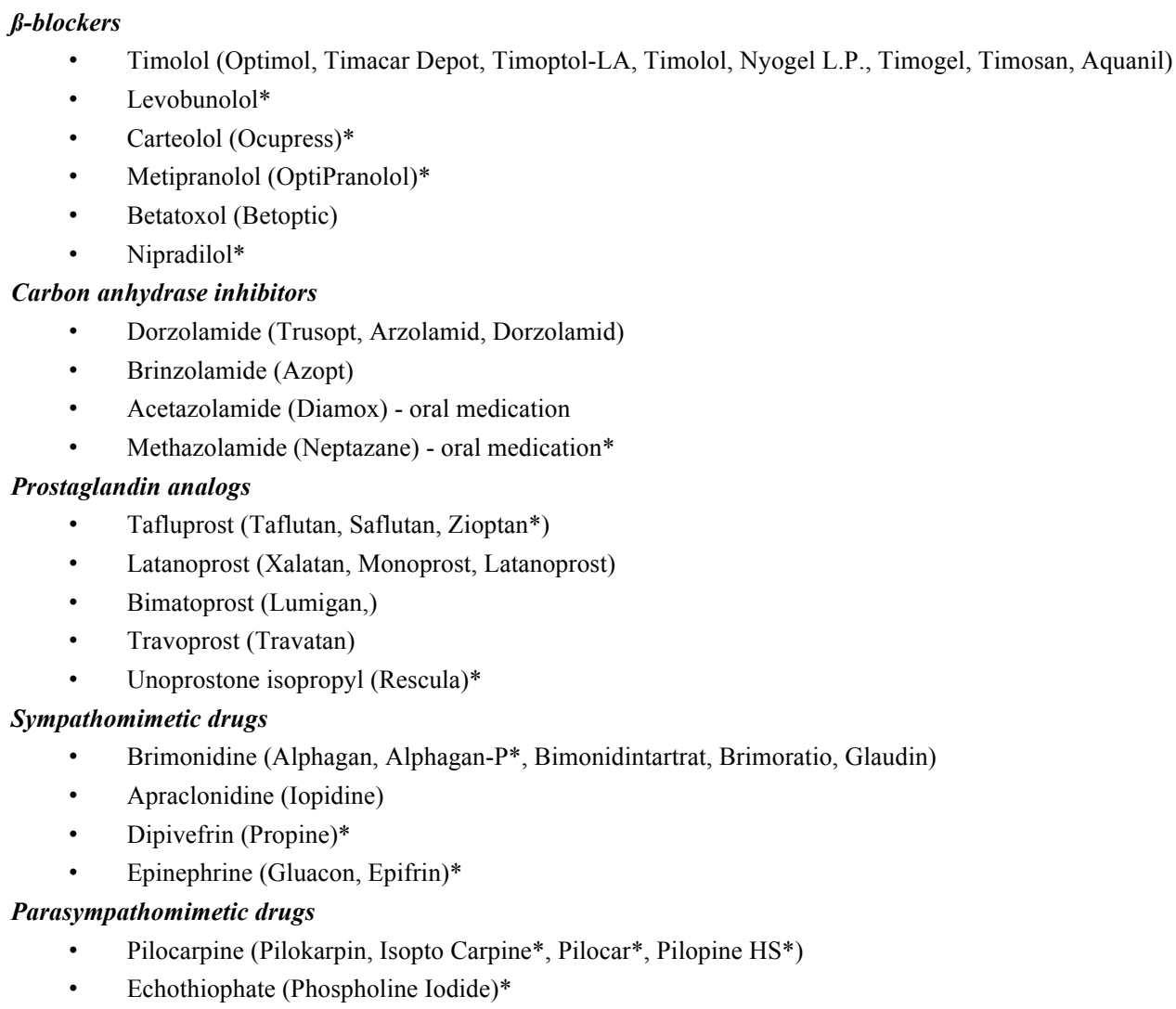

\section{Sympathomimetic Drugs}

Sympathomimetic drugs act on $\alpha 2$-receptors and activate $\mathrm{G}$ protein-coupled receptors, thereby reducing cAMP. In this way the production of aqueous humor production is reduced and the uveoscleral outflow increased. Allergic reactions frequently occur with this class of medication. Side effects may further include irregular heart rate, elevated blood pressure, headaches, blurred vision, fatigue, dry mouth, and redness in or around the eye [20]. A randomized trial of the a2-receptor agonist, brimonidine, versus the ß-blocker, timolol, found evidence of a less likely visual field progression in patients treated with brimonidine compared to timolol, thereby indicating a neuroprotective role of $\alpha 2$ agonists [21].

\section{Parasympathomimetic Drugs (Miotics)}

Parasympathomimetic drugs are cholinergic agents that cause the pupil to become much smaller in diameter and help increase the rate of fluid drainage from the eye. The most common ocular side effects include headache, red eyes, miosis-caused visual field constriction, and night vision loss. Systemic miotics may cause excessive salivation and tearing, sweating, diarrhea, vomiting, and slowed heartbeat [22].

In addition to the main therapeutic agents all eye drops contain additives, which stabilize the solution/suspension, and/or extend the life of the drugs. The draw back of additives is the ocular adverse reactions that follow these. Hence, more anti-glaucomatous drops now come in preservative free versions.

Another issue concerning adherence and adverse reactions is the increasing introduction of generic glaucoma medication. Within defined tolerances, generic drugs are "equivalent" to original, patented medications. There is, however, room for variability and error in manufacture, packaging, and the adjuvants can vary considerably. Because generic formulations do not necessarily undergo clinical testing, physicians and patients need to make sure that the medications are equally effective in real-life use. Even though the challenge of adverse reactions from preservatives, and the challenge of an increasing number of generic products are important issues, these topics are beyond the scope of this review.

\section{FUTURE TREATMENT STRATEGIES FOR GLAUCOMA}

Many mechanisms have been proposed to address the pathogenesis of glaucoma. However, none seems to characterize the disease sufficiently, and the multifactorial etiologies of glaucoma become a fundamental challenge in the development of new treatment strategies. Nevertheless elevated IOP together with yet-to-be elucidated cellular and molecular changes result in glaucomatous neurodegeneration. In this aspect treatment strategies can be grouped into 1) IOP 
Table 3. Targets for new treatment strategies in the management of glaucoma.

\begin{tabular}{|c|c|c|}
\hline IOP Lowering Strategies & Neuroprotective Strategies & Neuroregenerative Strategies \\
\hline $\begin{array}{c}\text { Increasing Trabecular Meshwork Outflow } \\
\text { ROCK } \\
\text { Endothelin-1 } \\
\text { Nitric Oxide } \\
\text { TGF- } \beta \\
\text { CTGF } \\
\text { Adenosine } \\
\text { Angiopoietin-like7 molecules } \\
\text { Cannabinoids } \\
\text { Cochlin } \\
\text { Latrunculins } \\
\text { Melatonin } \\
\text { Ghrelin } \\
\text { Angiotensin II } \\
\text { Serotonin } \\
\text { Ghrelin } \\
\text { Cannabinoids } \\
\text { Forskolin } \\
\text { Serotonin } \\
\text { Cannabinoids } \\
\text { Angiotensin II }\end{array}$ & $\begin{array}{c}\text { Exitotoxicity } \\
\text { NMDA antagonists (Memantine) } \\
\text { Modulation of Müller cells } \\
\text { Oxidative stress } \\
\text { Antioxidants ( } \alpha \text {-tocopherol) } \\
\text { Ginkgo Biloba } \\
\text { Mitochondrial Dysfunction } \\
\text { Mitochondrial targeted antioxidants (Q10) } \\
\text { Inflammation- Abnormal Immune Response } \\
\text { TNF- } \alpha \\
\text { Biological response modifiers (Ethanrecept) } \\
\text { Agmatine } \\
\text { Modulation of T-cell reaction (Cop-1) } \\
\text { Modulation of PLA }{ }_{2} \text {-induced inflammation } \\
\text { Protein Misfolding } \\
\text { Agents targeting A } 3 \\
\text { Heat shock proteins } \\
\text { Glial Cell Modulation } \\
\text { TGF- } \beta \text {, CNTF, PDGF } \\
\text { Other Pathways } \\
\text { Estradiol } \\
\text { Statins } \\
\text { Erythropoietin }\end{array}$ & $\begin{array}{c}\text { Cell Repair } \\
\text { Inflammatory stimulation (CNTF) } \\
\text { Gene Therapy (Nogo Receptor interference) } \\
\text { Surgical Approaches } \\
\text { Lens Injury } \\
\text { Stem Cell Therapy } \\
\text { CNTF-secreting RPE cells } \\
\text { MSC transplantation }\end{array}$ \\
\hline
\end{tabular}

Current treatment strategies. Abbreviations are: Rho-associated Kinase (ROCK), Tumor Growth Factor- $\beta$ (TGF- $\beta$ ), Connective Tissue Growth Factor (CTGF), Tumor Necrosis Factor- $\alpha$ (TNF- $\alpha$ ), Phospholipase $\mathrm{A}_{2}$ (PLA $)$, Amyloid- $\beta$ (Aß), Ciliary Neurotrophic Factor (CNTF), Platelet-derived Growth Factor (PDGF), Retinal Pigment Epithelial Cells (RPE), Mesenchymal Stem Cells (MSC).

lowering strategies, 2) neuroprotective strategies, and 3) neuroregenerative strategies (Table 3).

\section{NEW TREATMENT STRATEGIES FOR IOP LOWERING}

It is clear that multiple factors give rise to glaucomatous damage, and it is recognized that the most evident risk factor is IOP. The cause of elevated IOP in POAG is thought to be due to an increased accumulation of extracellular matrix material (ECM) in the TM. From the current approved glaucoma medications only prostaglandin analogues may have a role on modulation of the molecular changes that occur in the TM of glaucoma patients. Hence, prostaglandins may induce stimulation of matrix metalloproteinases, and in this way lead to increased spacing between the ciliary muscle bundles $[23,24]$.

Since the importance of IOP in the progression of glaucoma is evident, current new strategies target IOP lowering pathways. Among these exist two main approaches that try to increase the outflow facilities in the TM. The first strategy seeks to modulate the contractility of TM. It has been shown that TM possesses smooth muscle cell-like properties, and that TMs contractile properties can be regulated by several enzymes [25-29]. The second therapeutic concept includes alteration in the behavior of $\mathrm{TM}$, and strategies to affect the shape and loosen the cell-tocell junction and/or cell-to-ECM adhesion within the TM have become experimental targets for lowering IOP [30]. In addition, new therapeutic targets aim to decrease aqueous humor production or to improve the uveoscleral outflow by different subcellular pathways from those already existing [31-33].

\section{TREATMENT STRATEGIES TO INCREASE TRABECULAR MESHWORK OUTFLOW}

\section{Rho-Associated Kinase}

The Rho signaling pathway, mediated through Rhoassociated kinase (ROCK), plays a major role in regulation of smooth muscle contraction. Therefore, ROCK inhibitors may enhance aqueous drainage by acting on the actin cytoskeleton and cellular motility in the TM, Schlemms canal and ciliary muscle [34,35]. Multiple animal studies have shown an IOP reduction by topical use of ROCK inhibitors, and more ROCK inhibitors have been and are currently tested in clinical trials for glaucoma and ocular hypertension. The current (or completed without posted results) clinical trials include $\mathrm{K} 115$ (phase III, \#JapicCTI111565), AMA0076 (phase II, \#NCT01693315), AR-13324 (PG324) (phase III, \#NCT02057575), AR12286 (Phase II, \#NCT02174991/ \#NCT02173223) [36].

Although much attention is given to ROCK inhibition no drugs are yet on the market, and during the clinical trials concerns have been raised. Hence, ROCK inhibition in humans seems to elicit different IOP responses compared to animals and have resulted in side effects including moderate to severe hyperemia, vascular disorders and other system 
problems [37-39]. Overall, ROCK inhibitors, however, offer a potentially exciting alternative to the prostaglandin analogues, and if one tested target overcomes the side effects other beneficial effects of ROCK inhibition have been shown. Hence, in addition to ROCK inhibitors modulative effect on the TM, ROCK inhibition furthermore offers neuroprotective effects as well as enhances blood flow to the optic nerve [40].

\section{Endothelin-1}

Another modulator of TM is endothelin-1 (ET-1), and a significant correlation has been found between IOP and ET1[41-43]. Hence, increased ET-1 levels may stimulate contraction of both TM cells and the ECM, and thereby reduce TM outflow $[42,44]$. In addition to reduced TM outflow increased levels of ET-1 have been implicated in vascular dysregulation. In this matter raised concentrations of ET-1 in glaucoma patients may lead to vasoconstriction by stimulation of ET-1 receptors on the vascular smooth muscle cells $[45,46]$. In addition to a decreased IOP, ET-1 receptor inhibition has been shown to have neuroprotective effects [47]. Overall, an ET-1 receptor antagonist constitutes a potential treatment target to manage IOP reduction, which may also favor the vascular regulation and RGC survival.

\section{Nitric Oxide}

Nitric oxide (NO) has been implicated in more mechanisms related to glaucoma such as auto regulation [48], RGC survival and death [49], and low-grade inflammation [50]. Hence, dependent on the mechanism, it may be beneficial or damaging to glaucomatous progression. In relation to the IOP, NO agonists induce relaxation of TM cells and thereby increase the outflow [51,52].

\section{Transforming Growth Factor-ß乃}

Elevated levels of transforming growth factor- $\beta$ (TGF- $\beta$ ) have been identified in the anterior chamber of glaucomatous eyes [53], and increased levels of TGF- $\beta$ have been postulated to increase the risk of glaucoma [54]. TGF- $\beta$ has also been shown to directly cause increased IOP [55]. It is believed that this occurs through complex interactions with the TM, leading to decreased aqueous humor outflow $[55,56]$.

Beside a consistent beneficial effect by TGF- $\beta$ inhibition on IOP, the role of TGF- $\beta$ in RGC maintenance has contrasting beneficial effects. Hence, TGF- $\beta$ has multiple functions and among others, significant evidence shows a neuroprotective effect of TGF- $\beta$ [57-59]. Therefore, future potential clinical relevance of TGF- $\beta$ inhibition to reduce IOP requires attention to potential side effects.

\section{Connective Tissue Growth Factor}

Recent studies have described a complex relationship between increased connective tissue growth factor (CTGF) expression, TGF- $\beta$ activity, and fibrotic pathogenesis [6062], thereby highlighting the complex signaling interplay between CTGF and TGF- $\beta$ that results in increased fibrosis in the TM. Hence, interfering with CTGF expression may therefore prove beneficial in the treatment of glaucoma.

\section{Adenosine}

Adenosine and several adenosine derivatives increase and/or decrease IOP via modulation of $G$ protein coupled receptors [63]. There are four adenosine receptor subtypes known as A1, A2a, A2b, and A3. Activation of A1, A2a and A3 agonists and A3 antagonists has been shown to lower IOP by remodeling the ECM, through activation of metalloproteinases, and thereby increase TM outflow [32]. A3 receptor antagonists have been shown to prevent adenosine-induced activation of chloride channels of the ciliary non-pigmented epithelial cells followed by an IOP reduction [37,64]. Clinical trials are ongoing, but so far no significant results have been reported (Phase II, \#NCT01917383) [37].

\section{Other New Targets to Increase Trabecular Meshwork Outflow}

In the search for targets to increase TM outflow, multiple molecules are in consideration. Among these are angiopoietin-like7 (ANGPTL7), a member of the ANGPTL family, which has been shown to increase TM outflow [65]. Other potential molecules that could be targeted in the regulation of TM outflow are cannabinoids, cochlin, latrunculins, melatonin, and ghrelin [66].

\section{TREATMENT STRATEGIES TO INCREASE THE UVEOSCLERAL OUTFLOW}

\section{Angiotensin II}

Compounds that increase angiotensin-converting enzyme 2- (ACE2) activity and further the formation of angiotensin (1-7) are new options as anti-glaucomatous drugs in addition to classical ACE inhibitors and AT1 receptor blockers. Furthermore, drugs that activate the angiotensin receptor types, Mas receptors, directly have also been suggested as possible targets for IOP lowering [67].

\section{Other New Targets to Increase Uveoscleral Outflow}

In addition to angiotensin II treatment, targets such as serotonin [68], ghrelin [69], and cannabinoids [70] have also been suggested as potential drugs to increase the uveoscleral outflow [66].

\section{TREATMENT STRATEGIES TO DECREASE AQUEOUS HUMOR PRODUCTION}

\section{Forskolin}

Foskolin is a lipid-soluble compound that activates cAMP in the ciliary epithelium thereby reducing the aqueous humor production. It has been shown to be able to decrease IOP after topical application by a mechanism that is not used by the other drugs [71]. 


\section{Other New Targets to Decrease Aqueous Humor Production}

In addition to foskolin, targets such as serotonin, cannabinoids and angiotensin II have also been suggested as potential drugs that decrease the aqueous humor production [66].

\section{NON-IOP DEPENDENT TREATMENT STRATEGIES}

Beyond IOP, it is recognized that many other factors are associated with an increased risk of developing glaucoma. Hence, a significant number of glaucoma patients continue to lose vision despite successful IOP control, and it has been estimated that IOP-independent risk factors appear to be responsible for approximately 30-70 percent of glaucoma cases $[4,6,72,73]$.

A variety of non-IOP dependent risk factors are being proposed and in order to categorize and summarize the current knowledge, this review seeks to group these into two major groups i.e. neuroprotective- and neuroregenerativetreatment strategies.

\section{NEUROPROTECTIVE TREATMENT STRATEGIES}

In order to simplify the complexity of the proposed new neuroprotective treatment strategies, these can be grouped into targets that interfere with excitotoxicity, oxidative stress, mitochondrial dysfunction, inflammation - abnormal immune response, protein misfolding, and glial cell modulation. Obviously, such a division of treatment strategies is not definite and most targets will interfere with more pathways.

\section{Excitotoxicity}

Exitotoxicity refers to the pathological process by which neurons are damaged by the overactivation of glutamate receptors. In glaucoma, the initial insult to RGCs has been suggested to lead to elevated levels of extracellular glutamate [74-76]. In line with this, a chronic elevation of glutamate concentrations in the inner eye has been shown in glaucoma patients [77-79]. As a consequence of increased levels of glutamate, ionotropic N-methyl-D-aspartate (NMDA) receptors are overstimulated, resulting in a massive influx of calcium into the neurons, thereby causing glutamate-mediated RGC death. Strategies to modify glutamate-induced neurotoxicity have been widely studied, and in particular the NMDA antagonist, memantine, has been shown to be a highly effective neuroprotective agent in both acute and chronic animal models of RGC death [80-82].

In the well known memantine clinical trial no significant benefit was found in the memantine-treated group compared to the patients receiving placebo [83]. However, in line with the substantive evidence that glutamate promotes RGC death via NMDA over activation, the design and the clinical end points of the memantine study have been questioned and it still remains uncertain whether glutamate excitotoxicity is an efficient target for therapeutical intervention in glaucoma [83].
In addition to increased secretion of glutamate, reduced clearance by the Müller cells may account for excitotoxicity $[84,85]$. Hence, instead of, or together with, targeting the ionotropic glutamate receptors, the homeostasis of Müller cells could be a valuable target in the understanding of the homeostasis in the inner retina. Furthermore, the neurovascular junction (the interaction between pericytes, Müller cells and inner retinal neurons) may account for attention, since a dysfunctional nutrient and oxygen supply may affect the Müller cells ability to remove excess glutamate from the intercellular space and thereby their ability to protect the RGCs $[86,87]$.

\section{Oxidative Stress}

Oxidative stress reflects an imbalance between the production of reactive oxygen species (ROS) and the cells ability to readily detoxify the reactive intermediates or to repair the resulting damage. Significant evidence has shown that oxidative stress plays a role in RGC death in glaucoma, and the concept of antioxidants as a neuroprotective treatment strategy is widely accepted [88-92]. Among the most studied antioxidants, vitamin E ( $\alpha$-tocopherol) and gingko biloba have been shown to ameliorate NMDAinduced RGC death. Vitamin $\mathrm{E}$ acts as a scavenger of peroxyl radicals. Although some studies have suggested a decreased rate of glaucomatous progression in patients receiving vitamin $\mathrm{E}$ the long-term results are still lacking $[93,94]$. To further elucidate a role of vitamin $\mathrm{E}$ in the treatment of glaucoma, current studies are suggesting that vitamin $\mathrm{E}$, release from contact lenses may be used in preventing ROS-induced glaucomatous damage $[95,96]$.

Gingko biloba is an extract from Ginkgo biloba leaves. It increases blood flow and has been shown to have a free radical scavenger property [97]. In addition, gingko biloba has been shown to interfere with glutamate signaling and to preserve mitochondrial metabolism [98-100]. The precise mechanism by which gingko biloba interferes with RGC homeostasis is still not fully understood, however, the studied literature on gingko biloba is in favor of a possible beneficial effect on RGC survival [101].

\section{Mitochondrial Dysfunction}

In line with the role of oxidative stress in the pathogenesis of glaucoma, increasing evidence points to a mitochondrial dysfunction in glaucoma [102-105]. Even though many antioxidants have shown promising effects on RGC survival, many of them lack specificity to mitochondria, the key regulator of ROS production. Hence, compounds that specifically target the mitochondria have been suggested to be more beneficial. Among mitochondrialtargeted antioxidants, coenzyme Q10 (Q10) is one of the most studied targets, and in animal models, Q10 protects RGCs after ischemia [106,107] and oxidative stress [108]. To date, no human clinical trials have been published on the use of Q10 in glaucoma.

\section{Inflammation - Abnormal Immune Response}

It is widely accepted that glaucomatous neurodegeneration comes with an activation of glial cells and 
accompanying production of pro-inflammatory cytokines, such as tumor necrosis factor alpha (TNF- $\alpha$ ). TNF- $\alpha$ is secreted by damaged glial cells and through the binding of TNF-receptor-1 (TNF-R1) it causes apoptotic RGC death [109]. However, the binding of TNF-R1 also triggers the activation of transcription factor NF-KB, a cell survival pathway $[110,111]$. Overall, growing evidence exists on the role of TNF- $\alpha$ in RGC death [112-115], but opposing consequences of TNF- $\alpha$-signaling challenge any strategy for neuroprotection $[50,116]$.

More biologic response modifiers, such as ethanrecept, have been shown to possess promising results as neuroprotective agents by inhibiting TNF- $\alpha$-induced RGC damage [117].

Another anti-inflammatory agent, agmatine, has been shown to protect RGCs from TNF- $\alpha$-induced cell death $[118,119]$. In addition, it is known that agmatine protects neurons from apoptosis after exposure to NMDA and glutamate [120]. Finally, agmatine has a role as an $\alpha_{2}$ adrenergic agonist, and thus, can suppress RGC death by neuroprotective mechanisms, and also protect RGCs by lowering the IOP [121].

The inflammatory process in glaucoma has been found to be associated with pro-inflammatory activities mediated in part by $\mathrm{T}$ cell activity. In this aspect, Cop-1, a synthetic peptide polymer, has been shown to modulate this T-cell reaction by attenuating the normal inflammatory response. Furthermore, it has been shown experimentally that glutamate injections into the eye result in $\mathrm{T}$ cell reaction $[122,123]$, and in this aspect, Cop-1 immunization has shown some protection against RGC death [122-124].

A recognized inflammatory pathway is initiated by phospholipase $\mathrm{A}_{2}\left(\mathrm{PLA}_{2}\right)$ activity. Hence, PLA 2 activation leads to the cyclooxygenase-2 (COX-2)-mediated prostaglandin synthesis. Studies have shown an induction of COX-2 in RGCs in response to elevated IOP $[125,126]$. In line with this, COX-2 inhibition has been found to rescue RGCs [127].

The precursor of $\mathrm{COX}-2$ medicated prostaglandin synthesis is arachidonic acid (AA), which is released by $\mathrm{PLA}_{2}$-cleavage of phospholipids. Both AA and $\mathrm{PLA}_{2}$ have been shown to be involved in RGC maintenance. In this matter AA was found to ameliorate RGC death [128]. Opposing results have revealed a negative role of $\mathrm{PLA}_{2}$ on neuronal survival. Hence, PLA 2 has been shown to act synergistically with glutamate-induced exitotoxicity [129]. Moreover, levels of the PLA2 subgroup sPLA2-IIA was found to be increased in the aqueous humor of glaucoma patients $[130,131]$, and studies from the brain have revealed that increased levels of $\mathrm{PLA}_{2}$ instigate neuronal cell death [132-134].

\section{Protein Misfolding}

Protein aggregation is a prominent factor in neurodegenative disorders such as Alzheimer disease (AD). In $A D$, the peptide amyloid- $\beta(A \beta)$ has been implicated in the neuropathology, and growing evidence suggests that $A B$ aggregation is also involved in the development of RGC apoptosis. In line with this experimental studies for glaucoma support the involvement of $\mathrm{A} \beta$, and different agents targeting $A B$ formation have been shown to reduce RGC apoptosis in models of glaucoma [135-138].

In addition to $A \beta$ another mechanism of protein aggregation involves heat shock proteins (HSP). HSPs are thought to prevent the aggregation of denatured proteins and immunohistochemical analysis has demonstrated that HSP60 and -27 are greater in glaucomatous eyes compared to non glaucomatous eyes of humans [139], thereby suggesting that HSPs may be part of a defense mechanism that is activated in glaucomatous optic neuropathy. Furthermore, HSP72 upregulation has been shown to correlate with increased survival of RGCs in a rat model of acute glaucoma [140]. In glaucoma the HSP-inducer, geranylgeraylacetone, has furthermore been shown to induce HSP72 and thereby ameliorate RGC death. Even though no current HSPinducing drugs have been administered to glaucoma patients, it may be a future target for preventing glaucomatous damage $[141,142]$.

\section{Glial Cell Modulation}

Much attention has been given to RGC maintenance in the search for new treatment targets in glaucoma. However, it is clear, that the surrounding cells tightly regulate RGC homeostasis. Hence, in the non-myelinated region of the RGCs, Müller cells and astrocytes (macroglial cells) are the major glial cells to provide support, as well as to create the interface between RGCs and blood vessels. They remove excess glutamate from the synapse thereby preventing exitotoxicity [87,143], and help to maintain ion homeostasis and extracellular $\mathrm{pH}$. In addition, macroglial cells liberate cytokines such as TGF [144], ciliary neurotrophic factor (CNTF) [145], and platelet-derived growth factor [146]. Hence, modulation of macroglial cell activity may therefore be a key target in the understanding of RGC protection $[147,148]$.

\section{Other Pathways}

Considerable evidence exists on estrogen as a neuroprotective drug, and a recent study has provided strong evidence that topical estrogen drops are neuroprotective in a rodent model of glaucoma [149]. Another suggested drug to prevent glaucomatous damage is statins. Hence, long-term use of statins has been shown to be associated with a reduced risk of glaucoma [150,151]. Finally, the glycoprotein, erythropoietin (EPO), has been suggested to be a potential therapeutic neuroprotectant in glaucoma $[152,153]$.

\section{NEUROREGENERATIVE TREATMENT STRATEGIES}

Growing evidence suggests cell repair or cellreplacement therapy as a new treatment approach. Within the potential group of cell repair treatment strategies, axonal growth has become a target for investigation. Furthermore, surgical approaches to enhance regenerative capacity of RGCs have been suggested. Finally, stem cells hold great promise for neurodegenerative disorders such as glaucoma. 


\section{Cell Repair}

Although the critical first step in the treatment of glaucoma is enhancing RGC survival, a significant number of patients will be diagnosed at a later stage by which their axons have already been injured. In these cases, preventing apoptosis will not be sufficient and the ideal therapies should encourage axon regeneration to rebuild connections from the RGCs to the brain.

In this aspect, more molecules have been shown to possess regenerative properties due to their inflammatory stimulation [154-156]. Among these, CNTF has been shown to induce axonal growth and thereby suggested to provide a new neuroregenative approach $[147,157,158]$.

Because of the promising experimental results, a phase-I trial in glaucoma has recently been performed (Phase I, \# NCT01408472). Through search, no final outcome is yet available, however, although the study is a phase 1 trial and designed to evaluate safety in the patient population being studied, any hint of efficacy would be expected to drive investigation in later-phase trials.

In addition to $\mathrm{CNTF}$, studies have shown a potential role of Nogo-66 receptor (NgR)1 therapy for glaucoma to prevent RGC death and promote optic nerve axonal regeneration. Hence, inhibition of NgR1 by RNA interference or by transfection of the dominant-negative form of $\mathrm{NgR} 1$, has been shown to stimulate optic nerve axon regrowth. Furthermore, knockout of NgR1 has been shown effective for enhancing axonal regeneration after optic nerve crush $[159,160]$.

\section{Surgical Approaches for Neuroregeneration}

Penetrating injury as well as lens injury has been suggested to result in the release of low-grade inflammatory molecules, which secondly leads to axonal regeneration $[161,162]$. In order to consider this strategy in humans, a number of issues would have to be considered including a rapid formation of cataract, infection, etc. Hence, pursuing the molecular basis of the effect may prove more realistic for translation to human glaucoma treatment.

\section{Stem Cell Therapy}

Stem cell therapy holds great promise for neurodegenerative diseases and emerging studies try to identify the use of stem cells in experimental glaucoma. Substantial evidence has correlated neurotrophic factor deprivation with RGC death and new therapies aim to supplement these [163]. To avoid repeated injections of growth factors, cell-based delivery of neurotrophic factors have been proposed. In this matter, an ongoing phase-I clinical trial for glaucoma is using genetically modified CNTF-secreting retinal pigment epithelium cells (Phase I, \#NCT01408472). In addition, transplantation with mesenchymal stem cells (MSC) has been suggested, since these produce neurotrophic factors [164-167]. Furthermore, intracranial human umbilical cord blood MSC transplantation has been shown to protect RGC and to induce axonal regeneration [168]. Overall, the neuroprotective and neuroregenerative effect of MSCs on RGC survival is evident, and currently, a clinical trial using bone marrowderived MSCs on glaucoma is processed. The outcome of this study is expected in 2017 (Phase I, \#NCT01920867).

\section{CONCLUSION}

The present review highlights current treatment strategies and possible future ways to rescue and regenerate RGCs. Glaucoma remains a major cause of blindness worldwide. Various new targets to treat glaucoma have been suggested, but to date the only available glaucoma medication is IOP lowering compounds, which are only decreasing the rate of progression. Hence, no cure for glaucoma exists. The identification of new therapeutic targets has been hampered by lack of understanding of the etiology of glaucoma, and the limited number of animal models available that likely represent only a small subset of human glaucoma cases. Since glaucoma may be a spectrum of different pathologies leading to the same endpoint, the outcome from clinical trials may be lost in the diversification of etiologies. In order to identify future RGC rescuing drugs, attention must be given to the study design. Hence, a more stringent patient selection and more efficient outcome measurements will be necessary to document the effectiveness of these.

\section{CONFLICT OF INTEREST}

The authors confirm that this article content has no conflict of interest.

\section{ACKNOWLEDGEMENTS}

The time spent for writing the present review was granted by The Danish Council for Independent Research|Medical Sciences and the Velux Foundation for whom I am grateful. I thank Kurt Bang for providing information of currents treatment strategies, and for his enthusiasm of the present manuscript. My apologies to all colleagues whose work I have not included.

\section{REFERENCES}

[1] Tham Y-C, Li X, Wong TY, Quigley HA, Aung T, Cheng C-Y. Global prevalence of glaucoma and projections of glaucoma burden through 2040: a systematic review and meta-analysis. Ophthalmology 2014; 121(11): 2081-90.

[2] Chang EE, Goldberg JL. Glaucoma 2.0: neuroprotection, neuroregeneration, neuroenhancement. Ophthalmology 2012; 119(5): 979-86.

[3] Gordon MO, Beiser JA, Brandt JD, et al. The ocular hypertension treatment study: baseline factors that predict the onset of primary open-angle glaucoma. Arch Ophthalmol 2002; 120(6): 714-20 discussion 829-30.

[4] Pinazo-Durán MD, Zanón-Moreno V, García-Medina JJ, GallegoPinazo R. Evaluation of presumptive biomarkers of oxidative stress, immune response and apoptosis in primary open-angle glaucoma. Curr Opin Pharmacol 2013; 13(1): 98-107.

[5] Weinreb RN. Glaucoma neuroprotection: What is it? why is it needed? Can J Ophthalmol 2007; 42(3): 396-8.

[6] Wierzbowska J, Robaszkiewicz J, Figurska M, Stankiewicz A. Future possibilities in glaucoma therapy. Med Sci Monit 2010; 16(11): RA252-9.

[7] Heijl A, Bengtsson B, Hyman L, Leske MC, Early Manifest Glaucoma Trial Group. Natural history of open-angle glaucoma. Ophthalmology 2009; 116(12): 2271-6.

[8] Quigley HA. Glaucoma. Lancet 2011; 377(9774): 1367-77. 
[9] Metoki T, Ohguro H, Ohguro I, Mamiya K, Ito T, Nakazawa M. Study of effects of antiglaucoma eye drops on N-methyl-Daspartate-induced retinal damage. Jpn J Ophthalmol 2005; 49(6): $453-61$.

[10] Mizuno K, Koide T, Yoshimura M, Araie M. Neuroprotective effect and intraocular penetration of nipradilol, a beta-blocker with nitric oxide donative action. Invest Ophthalmol Vis Sci 2001; 42(3): 688-94

[11] Mizuno K, Koide T, Saito N, et al. Topical nipradilol: effects on optic nerve head circulation in humans and periocular distribution in monkeys. Invest Ophthalmol Vis Sci 2002; 43(10): 3243-50.

[12] Inoue $\mathrm{K}$, Okugawa $\mathrm{K}$, Kato $\mathrm{S}$, et al. Ocular factors relevant to antiglaucomatous eyedrop-related keratoepitheliopathy. J Glaucoma $2003 ; 12(6)$ : 480-5

[13] Schoene RB, Abuan T, Ward RL, Beasley CH. Effects of topical betaxolol, timolol, and placebo on pulmonary function in asthmatic bronchitis. Am J Ophthalmol 1984; 97(1): 86-92.

[14] Lichter PR, Newman LP, Wheeler NC, Beall OV. Patient tolerance to carbonic anhydrase inhibitors. Am J Ophthalmol 1978; 85(4): 495-502.

[15] Konowal A, Morrison JC, Brown SV, et al. Irreversible corneal decompensation in patients treated with topical dorzolamide. Am J Ophthalmol 1999; 127(4): 403-6.

[16] Inoue $\mathrm{K}$, Wakakura $\mathrm{M}$, Inoue $\mathrm{J}$, Matsuo $\mathrm{H}$, Hara $\mathrm{T}$, Tomita $\mathrm{G}$. Adverse reaction after use of latanoprost in Japanese glaucoma patients. Nippon Ganka Gakkai Zasshi 2006; 110(8): 581-7.

[17] Camras CB, Alm A, Watson P, Stjernschantz J. Latanoprost, a prostaglandin analog, for glaucoma therapy. Efficacy and safety after 1 year of treatment in 198 patients. Latanoprost Study Groups. Ophthalmology 1996; 103(11): 1916-24.

[18] Inoue K, Shiokawa M, Higa R, et al. Adverse periocular reactions to five types of prostaglandin analogs. Eye (Lond) 2012; 26(11): 1465-72.

[19] Wand M, Gilbert CM, Liesegang TJ. Latanoprost and herpes simplex keratitis. Am J Ophthalmol 1999; 127(5): 602-4.

[20] Butler P, Mannschreck M, Lin S, Hwang I, Alvarado J. Clinical experience with the long-term use of $1 \%$ apraclonidine. Incidence of allergic reactions. Arch Ophthalmol 1995; 113(3): 293-6.

[21] Krupin T, Liebmann JM, Greenfield DS, Ritch R, Gardiner S, Low-Pressure Glaucoma Study Group. A randomized trial of brimonidine versus timolol in preserving visual function: results from the low-pressure glaucoma treatment study. Am J Ophthalmol 2011; 151(4): 671-81.

[22] Zimmerman TJ, Wheeler TM. Miotics: side effects and ways to avoid them. Ophthalmology 1982; 89(1): 76-80.

[23] Weinreb RN, Lindsey JD. Metalloproteinase gene transcription in human ciliary muscle cells with latanoprost. Invest Ophthalmol Vis Sci 2002; 43(3): 716-22

[24] Weinreb RN, Toris CB, Gabelt BT, Lindsey JD, Kaufman PL. Effects of prostaglandins on the aqueous humor outflow pathways. Surv Ophthalmol 2002; 47(Suppl 1): S53-64.

[25] Fukata Y, Amano M, Kaibuchi K. Rho-rho-kinase pathway in smooth muscle contraction and cytoskeletal reorganization of nonmuscle cells. Trends Pharmacol Sci 2001; 22(1): 32-9.

[26] Honjo M, Tanihara H, Inatani M, et al. Effects of rho-associated protein kinase inhibitor Y-27632 on intraocular pressure and outflow facility. Invest Ophthalmol Vis Sci 2001; 42(1): 137-44.

[27] Rao PV, Deng P, Sasaki Y, Epstein DL. Regulation of myosin light chain phosphorylation in the trabecular meshwork: role in aqueous humour outflow facility. Exp Eye Res 2005; 80(2): 197-206.

[28] Tian B, Geiger B, Epstein DL, Kaufman PL. Cytoskeletal involvement in the regulation of aqueous humor outflow. Invest Ophthalmol Vis Sci 2000; 41(3): 619-23.

[29] Tian B, Brumback LC, Kaufman PL. ML-7, chelerythrine and phorbol ester increase outflow facility in the monkey eye. Exp Eye Res 2000; 71(6): 551-66.

[30] Kaufman PL. Pharmacologic trabeculocanalotomy. Facilitating aqueous outflow by assaulting the meshwork cytoskeleton, junctional complexes, and extracellular matrix. Arch Ophthalmol 1992; 110(1): 34-6.

[31] Beidoe G, Mousa SA. Current primary open-angle glaucoma treatments and future directions. Clin Ophthalmol 2012; 6: 1699707.

[32] Lee AJ, Goldberg I. Emerging drugs for ocular hypertension. Expert Opin Emerg Drugs 2011; 16(1): 137-61.
[33] Muñoz-Negrete FJ, Pérez-López M, Kim HRW, Rebolleda G. New developments in glaucoma medical treatment. Arch Soc Esp Oftalmol 2009; 84(10): 491-500.

[34] Fukiage C, Mizutani K, Kawamoto Y, Azuma M, Shearer TR. Involvement of phosphorylation of myosin phosphatase by ROCK in trabecular meshwork and ciliary muscle contraction. Biochem Biophys Res Commun 2001; 288(2): 296-300.

[35] Nakajima E, Nakajima T, Minagawa Y, Shearer TR, Azuma M. Contribution of ROCK in contraction of trabecular meshwork: proposed mechanism for regulating aqueous outflow in monkey and human eyes. J Pharm Sci 2005; 94(4): 701-8.

[36] Vohra V, Chawla H, Malvika G. Rock inhibitors: future of antiglaucoma medication. Ophthalmol Res 2014; 2(6): 361-7.

[37] Chen J, Runyan SA, Robinson MR. Novel ocular antihypertensive compounds in clinical trials. Clin Ophthalmol 2011; 5: 667-77.

[38] Tanihara H, Inatani M, Honjo M, Tokushige H, Azuma J, Araie M. Intraocular pressure-lowering effects and safety of topical administration of a selective ROCK inhibitor, SNJ-1656, in healthy volunteers. Arch Ophthalmol 2008; 126(3): 309-15.

[39] Tokushige $\mathrm{H}$, Inatani $\mathrm{M}$, Nemoto $\mathrm{S}$, et al. Effects of topical administration of y-39983, a selective rho-associated protein kinase inhibitor, on ocular tissues in rabbits and monkeys. Invest Ophthalmol Vis Sci 2007; 48(7): 3216-22.

[40] Rao VP, Epstein DL. Rho GTPase/Rho kinase inhibition as a novel target for the treatment of glaucoma. BioDrugs 2007; 21(3): 167 77 .

[41] Sugiyama T, Moriya S, Oku H, Azuma I. Association of endothelin-1 with normal tension glaucoma: clinical and fundamental studies. Surv Ophthalmol 1995; 39(Suppl 1): S49-56.

[42] Choritz L, Machert M, Thieme H. Correlation of endothelin-1 concentration in aqueous humor with intraocular pressure in primary open angle and pseudoexfoliation glaucoma. Invest Ophthalmol Vis Sci 2012; 53(11): 7336-42.

[43] Källberg ME, Brooks DE, Gelatt KN, Garcia-Sanchez GA, Szabo NJ, Lambrou GN. Endothelin-1, nitric oxide, and glutamate in the normal and glaucomatous dog eye. Vet Ophthalmol 2007; 10(Suppl 1): 46-52.

[44] Renieri G, Choritz L, Rosenthal R, Meissner S, Pfeiffer N, Thieme H. Effects of endothelin-1 on calcium-independent contraction of bovine trabecular meshwork. Graefes Arch Clin Exp Ophthalmol 2008; 246(8): 1107-15.

[45] Cellini M, Strobbe E, Gizzi C, Balducci N, Toschi PG, Campos EC. Endothelin-1 plasma levels and vascular endothelial dysfunction in primary open angle glaucoma. Life Sci 2012; 91(1314): 699-702.

[46] Buckley C, Hadoke PWF, Henry E, O'Brien C. Systemic vascular endothelial cell dysfunction in normal pressure glaucoma. Br J Ophthal 2002; 86(2): 227-32.

[47] Minton AZ, Phatak NR, Stankowska DL, et al. Endothelin B receptors contribute to retinal ganglion cell loss in a rat model of glaucoma. PLoS ONE 2012; 7(8): e43199.

[48] Cherecheanu AP, Garhofer G, Schmidl D, Werkmeister R, Schmetterer L. Ocular perfusion pressure and ocular blood flow in glaucoma. Curr Opin Pharmacol 2013; 13(1): 36-42.

[49] Neufeld AH. Pharmacologic neuroprotection with an inhibitor of nitric oxide synthase for the treatment of glaucoma. Brain Res Bull 2004; 62(6): 455-9.

[50] Vohra R, Tsai JC, Kolko M. The role of inflammation in the pathogenesis of glaucoma. Surv Ophthalmol 2013; 58(4): 311-20.

[51] Nathanson JA, McKee M. Identification of an extensive system of nitric oxide-producing cells in the ciliary muscle and outflow pathway of the human eye. Invest Ophthalmol Vis Sci 1995; 36(9): 1765-73.

[52] Wiederholt M, Thieme H, Stumpff F. The regulation of trabecular meshwork and ciliary muscle contractility. Prog Retin Eye Res 2000; 19(3): 271-95.

[53] Min SH, Lee T-I, Chung YS, Kim HK. Transforming growth factor-beta levels in human aqueous humor of glaucomatous, diabetic and uveitic eyes. Korean J Ophthalmol 2006; 20(3): 162-5.

[54] Trivedi RH, Nutaitis M, Vroman D, Crosson CE. Influence of race and age on aqueous humor levels of transforming growth factorbeta 2 in glaucomatous and nonglaucomatous eyes. J Ocul Pharmacol Ther 2011; 27(5): 477-80.

[55] Prendes MA, Harris A, Wirostko BM, Gerber AL, Siesky B. The role of transforming growth factor $\beta$ in glaucoma and the therapeutic implications. Br J Ophthalmol 2013; 97(6): 680-6. 
[56] Gottanka J, Chan D, Eichhorn M, Lütjen-Drecoll E, Ethier CR. Effects of TGF-beta2 in perfused human eyes. Invest Ophthalmol Vis Sci 2004; 45(1): 153-8.

[57] Walshe TE, Leach LL, D'Amore PA. TGF- $\beta$ signaling is required for maintenance of retinal ganglion cell differentiation and survival. Neuroscience 2011; 189: 123-31.

[58] Ueda K, Nakahara T, Mori A, Sakamoto K, Ishii K. Protective effects of TGF- $\beta$ inhibitors in a rat model of NMDA-induced retinal degeneration. Eur J Pharmacol 2013; 699(1-3): 188-93.

[59] Tao Y-J, Gao D-W, Yu M. TGF- $\beta(1)$ in retinal ganglion cells in rats with chronic ocular hypertension: its expression and antiapoptotic effect. Int J Ophthalmol 2011; 4(4): 396-401.

[60] Wang Q, Usinger W, Nichols B, et al. Cooperative interaction of CTGF and TGF- $\beta$ in animal models of fibrotic disease. Fibrogenesis Tissue Repair 2011; 4(1): 4 .

[61] O'Donovan HC, Hickey F, Brazil DP, et al. Connective tissue growth factor antagonizes transforming growth factor- $\beta 1 / \mathrm{Smad}$ signalling in renal mesangial cells. Biochem J 2012; 441(1): 499510

[62] Faherty N, Curran SP, O'Donovan $\mathrm{H}$, et al. CCN2/CTGF increases expression of miR-302 microRNAs, which target the TGF $\beta$ type II receptor with implications for nephropathic cell phenotypes. J Cell Sci 2012; 125(Pt 23): 5621-9.

[63] Fredholm BB. Adenosine receptors as drug targets. Exp Cell Res 2010; 316(8): 1284-8

[64] Civan MM, Macknight ADC. The ins and outs of aqueous humour secretion. Exp Eye Res 2004; 78(3): 625-31.

[65] Comes N, Buie LK, Borrás T. Evidence for a role of angiopoietinlike 7 (ANGPTL7) in extracellular matrix formation of the human trabecular meshwork: implications for glaucoma. Genes Cells 2011; 16(2): 243-59.

[66] Rocha-Sousa A, Rodrigues-Araújo J, Gouveia P, et al. New therapeutic targets for intraocular pressure lowering. ISRN Ophthalmol 2013; 2013: 261386

[67] Vaajanen A, Vapaatalo H. Local ocular renin-angiotensin system a target for glaucoma therapy? Basic Clin Pharmacol Toxicol 2011; 109(4): 217-24

[68] Costagliola C, Parmeggiani F, Semeraro F, Sebastiani A. Selective serotonin reuptake inhibitors: a review of its effects on intraocular pressure. Curr Neuropharmacol 2008; 6(4): 293-310.

[69] Rocha-Sousa A, Pereira-Silva P, Tavares-Silva $\mathrm{M}$, et al. Identification of the ghrelin-GHSR 1 system and its influence in the modulation of induced ocular hypertension in rabbit and rat eyes. Peptides 2014; 57: 59-66.

[70] Pinar-Sueiro S, Rodríguez-Puertas R, Vecino E. Cannabinoid applications in glaucoma. Arch Soc Esp Oftalmol 2011; 86(1): 1623.

[71] Metzger H, Lindner E. The positive inotropic-acting forskolin, a potent adenylate cyclase activator. Arzneimittelforschung 1981; 31(8): 1248-50.

[72] Armaly MF, Krueger DE, Maunder L, et al. Biostatistical analysis of the collaborative glaucoma study. I. Summary report of the risk factors for glaucomatous visual-field defects. Arch Ophthalmol 1980; 98(12): 2163-71.

[73] Shiose Y, Kitazawa Y, Tsukahara S, et al. Epidemiology of glaucoma in Japan--a nationwide glaucoma survey. Jpn J Ophthalmol 1991; 35(2): 133-55.

[74] Furuya T, Pan Z, Kashiwagi K. Role of retinal glial cell glutamate transporters in retinal ganglion cell survival following stimulation of NMDA receptor. Curr Eye Res 2012; 37(3): 170-8.

[75] Lipton SA, Rosenberg PA. Excitatory amino acids as a final common pathway for neurologic disorders. N Engl J Med 1994; 330(9): 613-22.

[76] Salt TE, Cordeiro MF. Glutamate excitotoxicity in glaucoma: throwing the baby out with the bathwater? Eye (Lond) 2006; 20(6): 730-32.

[77] Brooks DE, Garcia GA, Dreyer EB, Zurakowski D, FrancoBourland RE. Vitreous body glutamate concentration in dogs with glaucoma. Am J Vet Res 1997; 58(8): 864-7.

[78] Dreyer EB, Zurakowski D, Schumer RA, Podos SM, Lipton SA. Elevated glutamate levels in the vitreous body of humans and monkeys with glaucoma. Arch Ophthalmol 1996; 114(3): 299-305.

[79] Johnson EC, Deppmeier LM, Wentzien SK, Hsu I, Morrison JC. Chronology of optic nerve head and retinal responses to elevated intraocular pressure. Invest Ophthalmol Vis Sci 2000; 41(2): 43142 .
[80] Greenfield DS, Girkin C, Kwon YH. Memantine and progressive glaucoma. J Glaucoma 2005; 14(1): 84-6.

[81] Hare WA, WoldeMussie E, Lai RK, et al. Efficacy and safety of memantine treatment for reduction of changes associated with experimental glaucoma in monkey, I: Functional measures. Invest Ophthalmol Vis Sci 2004; 45(8): 2625-39.

[82] Miguel-Hidalgo JJ, Alvarez XA, Cacabelos R, Quack G Neuroprotection by memantine against neurodegeneration induced by beta-amyloid(1-40). Brain Res 2002; 958(1): 210-21.

[83] Osborne NN. Recent clinical findings with memantine should not mean that the idea of neuroprotection in glaucoma is abandoned. Acta Ophthalmol 2009; 87(4): 450-4.

[84] Martin KRG, Levkovitch-Verbin H, Valenta D, Baumrind L, Pease ME, Quigley HA. Retinal glutamate transporter changes in experimental glaucoma and after optic nerve transection in the rat Invest Ophthalmol Vis Sci 2002; 43(7): 2236-43.

[85] Sullivan RKP, WoldeMussie E, Macnab L, Ruiz G, Pow DV Evoked expression of the glutamate transporter GLT-1c in retinal ganglion cells in human glaucoma and in a rat model. Invest Ophthalmol Vis Sci 2006; 47(9): 3853-9.

[86] Attwell D, Buchan AM, Charpak S, Lauritzen M, Macvicar BA, Newman EA. Glial and neuronal control of brain blood flow. Nature 2010; 468(7321): 232-43.

[87] Toft-Kehler AK, Skytt DM, Poulsen KA, et al. Limited energy supply in Müller cells alters glutamate uptake. Neurochem Res 2014; 39(5): 941-9.

[88] Feilchenfeld Z, Yücel YH, Gupta N. Oxidative injury to blood vessels and glia of the pre-laminar optic nerve head in human glaucoma. Exp Eye Res 2008; 87(5): 409-14.

[89] Javadiyan S, Burdon KP, Whiting MJ, et al. Elevation of serum asymmetrical and symmetrical dimethylarginine in patients with advanced glaucoma. Invest Ophthalmol Vis Sci 2012; 53(4): 19237.

[90] Ko M-L, Peng P-H, Ma M-C, Ritch R, Chen C-F. Dynamic changes in reactive oxygen species and antioxidant levels in retinas in experimental glaucoma. Free Radic Biol Med 2005; 39(3): 36573 .

[91] Moreno MC, Campanelli J, Sande P, Sánez DA, Keller Sarmiento MI, Rosenstein RE. Retinal oxidative stress induced by high intraocular pressure. Free Radic Biol Med 2004; 37(6): 80312.

[92] Tezel G, Yang X, Cai J. Proteomic identification of oxidatively modified retinal proteins in a chronic pressure-induced rat model of glaucoma. Invest Ophthalmol Vis Sci 2005; 46(9): 3177-87.

[93] Birich TV, Birich TA, Marchenko LN, Remizonova DN, Fedylov AS. Vitamin $\mathrm{E}$ in the complex treatment of patients with primary glaucoma. Vestn Oftalmol 1986; 102(2): 10-3.

[94] Cellini M, Caramazza N, Mangiafico P, Possati GL, Caramazza R. Fatty acid use in glaucomatous optic neuropathy treatment. Acta Ophthalmol Scand 1998; 227: 41-2.

[95] Hsu K-H, Lazon de la Jara P, Ariyavidana A, et al. Release of betaine and dexpanthenol from vitamin $\mathrm{E}$ modified siliconehydrogel contact lenses. Curr Eye Res 2014; 15: 1-7.

[96] Peng C-C, Ben-Shlomo A, Mackay EO, Plummer CE, Chauhan A. Drug delivery by contact lens in spontaneously glaucomatous dogs. Curr Eye Res 2012; 37(3): 204-11.

[97] Janssens D, Michiels C, Delaive E, Eliaers F, Drieu K, Remacle J. Protection of hypoxia-induced ATP decrease in endothelial cells by ginkgo biloba extract and bilobalide. Biochem Pharmacol 1995; 50(7): 991-9.

[98] Abdel-Kader R, Hauptmann S, Keil U, et al. Stabilization of mitochondrial function by Ginkgo biloba extract (EGb 761). Pharmacol Res 2007; 56(6): 493-502.

[99] Chandrasekaran K, Mehrabian Z, Spinnewyn B, Chinopoulos C, Drieu K, Fiskum G. Bilobalide, a component of the Ginkgo biloba extract (EGb 761), protects against neuronal death in global brain ischemia and in glutamate-induced excitotoxicity. Cell Mol Biol (Noisy-le-grand) 2002; 48(6): 663-9.

[100] Eckert A, Keil U, Scherping I, Hauptmann S, Müller WE. Stabilization of mitochondrial membrane potential and improvement of neuronal energy metabolism by Ginkgo biloba extract EGb 761. Ann N Y Acad Sci 2005; 1056: 474-85.

[101] Cybulska-Heinrich AK, Mozaffarieh M, Flammer J. Ginkgo biloba an adjuvant therapy for progressive normal and high tension glaucoma. Mol Vis 2012; 18: 390-402. 
[102] Abu-Amero KK, Morales J, Bosley TM. Mitochondrial abnormalities in patients with primary open-angle glaucoma. Invest Ophthalmol Vis Sci 2006; 47(6): 2533-41.

[103] Chrysostomou V, Rezania F, Trounce IA, Crowston JG. Oxidative stress and mitochondrial dysfunction in glaucoma. Curr Opin Pharmacol 2013; 13(1): 12-5.

[104] Lee S, Sheck L, Crowston JG, et al. Impaired complex-I-linked respiration and ATP synthesis in primary open-angle glaucoma patient lymphoblasts. Invest Ophthalmol Vis Sci 2012; 53(4): 2431-7.

[105] Yu-Wai-Man P, Griffiths PG, Chinnery PF. Mitochondrial optic neuropathies - disease mechanisms and therapeutic strategies. Prog Retinal Eye Res 2011; 30(2): 81-114.

[106] Nucci C, Tartaglione R, Cerulli A, et al. Retinal damage caused by high intraocular pressure-induced transient ischemia is prevented by coenzyme Q10 in rat. Int Rev Neurobiol 2007; 82: 397-406.

[107] Russo R, Cavaliere F, Rombolà L, et al. Rational basis for the development of coenzyme Q10 as a neurotherapeutic agent for retinal protection. Prog Brain Res 2008; 173: 575-82.

[108] Nakajima Y, Inokuchi Y, Nishi M, Shimazawa M, Otsubo K, Hara H. Coenzyme Q10 protects retinal cells against oxidative stress in vitro and in vivo. Brain Res 2008; 1226: 226-33.

[109] McKinnon SJ. The cell and molecular biology of glaucoma: common neurodegenerative pathways and relevance to glaucoma. Invest Ophthalmol Vis Sci 2012; 53(5): 2485-7.

[110] Agarwal R, Agarwal P. Glaucomatous neurodegeneration: an eye on tumor necrosis factor-alpha. Indian J Ophthalmol 2012; 60(4): 255-61.

[111] Tezel G. TNF-alpha signaling in glaucomatous neurodegeneration. Prog Brain Res 2008; 173: 409-21.

[112] Fontaine V, Mohand-Said S, Hanoteau N, Fuchs C, Pfizenmaier K, Eisel U. Neurodegenerative and neuroprotective effects of tumor Necrosis factor (TNF) in retinal ischemia: opposite roles of TNF receptor 1 and TNF receptor 2. J Neurosci 2002; 22(7): RC216.

[113] Lebrun-Julien F, Bertrand MJ, De Backer O, et al. ProNGF induces TNFalpha-dependent death of retinal ganglion cells through a p75NTR non-cell-autonomous signaling pathway. Proc Natl Acad Sci USA 2010; 107(8): 3817-22.

[114] Nakazawa T, Nakazawa C, Matsubara A, et al. Tumor necrosis factor-alpha mediates oligodendrocyte death and delayed retinal ganglion cell loss in a mouse model of glaucoma. J Neurosci 2006; 26(49): 12633-41.

[115] Tezel G, Yang X, Yang J, Wax MB. Role of tumor necrosis factor receptor-1 in the death of retinal ganglion cells following optic nerve crush injury in mice. Brain Res 2004; 996(2): 202-12.

[116] Ahmed Z, Aslam M, Lorber B, Suggate EL, Berry M, Logan A. Optic nerve and vitreal inflammation are both RGC neuroprotective but only the latter is RGC axogenic. Neurobiol Dis 2010; 37(2): 441-54.

[117] Roh M, Zhang Y, Murakami Y, et al. Etanercept, a widely used inhibitor of tumor necrosis factor- $\alpha$ (TNF- $\alpha)$, prevents retinal ganglion cell loss in a rat model of glaucoma. PLoS ONE 2012; 7(7): e40065.

[118] Dong C-J, Guo Y, Agey P, Wheeler L, Hare WA. Alpha2 adrenergic modulation of NMDA receptor function as a major mechanism of RGC protection in experimental glaucoma and retinal excitotoxicity. Invest Ophthalmol Vis Sci 2008; 49(10): 4515-22.

[119] Pan Y-Z, Li D-P, Pan H-L. Inhibition of glutamatergic synaptic input to spinal lamina II(o) neurons by presynaptic alpha(2)adrenergic receptors. J Neurophysiol 2002; 87(4): 1938-47.

[120] Hong S, Park K, Kim CY, Seong GJ. Agmatine inhibits hypoxiainduced TNF-alpha release from cultured retinal ganglion cells. Biocell 2008; 32(2): 201-5.

[121] Hong S, Kim CY, Lee WS, Shim J, Yeom HY, Seong GJ. Ocular hypotensive effects of topically administered agmatine in a chronic ocular hypertensive rat model. Exp Eye Res 2010; 90(1): 97-103.

[122] García E, Silva-García R, Mestre H, et al. Immunization with A91 peptide or copolymer-1 reduces the production of nitric oxide and inducible nitric oxide synthase gene expression after spinal cord injury. J Neurosci Res 2012; 90(3): 656-63.

[123] Schori H, Kipnis J, Yoles E, et al. Vaccination for protection of retinal ganglion cells against death from glutamate cytotoxicity and ocular hypertension: implications for glaucoma. Proc Natl Acad Sci USA 2001; 98(6): 3398-403.
[124] Nilforushan N. Neuroprotection in glaucoma. J Ophthalmic Vis Res 2012; 7(1): 91-3.

[125] Brust A-K, Ulbrich HK, Seigel GM, Pfeiffer N, Grus FH. Effects of cyclooxygenase inhibitors on apoptotic neuroretinal cells. Biomark Insights 2008; 3: 387-402.

[126] Collaço-Moraes Y, Aspey B, Harrison M, de Belleroche J. Cyclooxygenase-2 messenger RNA induction in focal cerebral ischemia. J Cereb Blood Flow Metab 1996; 16(6): 1366-72.

[127] Sakai Y, Tanaka T, Seki M, et al. Cyclooxygenase-2 plays a critical role in retinal ganglion cell death after transient ischemia: real-time monitoring of RGC survival using Thy-1-EGFP transgenic mice. Neurosci Res 2009; 65(4): 319-25.

[128] Kawasaki A, Han M-H, Wei J-Y, Hirata K, Otori Y, Barnstable CJ. Protective effect of arachidonic acid on glutamate neurotoxicity in rat retinal ganglion cells. Invest Ophthalmol Vis Sci 2002; 43(6) $1835-42$

[129] Kolko M, DeCoster MA, de Turco EB, Bazan NG. Synergy by secretory phospholipase A2 and glutamate on inducing cell death and sustained arachidonic acid metabolic changes in primary cortical neuronal cultures. J Biol Chem 1996; 271(51): 32722-8.

[130] Helin M, Rönkkö S, Puustjärvi T, Teräsvirta M, Uusitalo $H$ Phospholipases A2 in normal human conjunctiva and from patients with primary open-angle glaucoma and exfoliation glaucoma. Graefes Arch Clin Exp Ophthalmol 2008; 246(5): 739-46.

[131] Rönkkö S, Rekonen P, Kaarniranta K, Puustjärvi T, Teräsvirta M Uusitalo H. Phospholipase A2 in chamber angle of normal eyes and patients with primary open angle glaucoma and exfoliation glaucoma. Mol Vis 2007; 13: 408-17.

[132] Yagami T, Ueda K, Sakaeda T, et al. Effects of an endothelin B receptor agonist on secretory phospholipase A2-IIA-induced apoptosis in cortical neurons. Neuropharmacology 2005; 48(2): 291-300.

[133] Yagami T, Ueda K, Asakura K, et al. Human group IIA secretory phospholipase A2 induces neuronal cell death via apoptosis. Mol Pharmacol 2002; 61(1): 114-26.

[134] Yagami T, Ueda K, Asakura K, et al. Human group IIA secretory phospholipase $\mathrm{A} 2$ potentiates $\mathrm{Ca}^{2+}$ influx through L-type voltagesensitive $\mathrm{Ca}^{2+}$ channels in cultured rat cortical neurons. J Neurochem 2003; 85(3): 749-58.

[135] Doh SH, Kim JH, Lee KM, Park HY, Park CK. Retinal ganglion cell death induced by endoplasmic reticulum stress in a chronic glaucoma model. Brain Res 2010; 1308: 158-66.

[136] Guo L, Salt TE, Luong V, et al. Targeting amyloid-beta in glaucoma treatment. Proc Natl Acad Sci USA 2007; 104(33): 13444-9.

[137] McKinnon SJ, Lehman DM, Kerrigan-Baumrind LA, et al. Caspase activation and amyloid precursor protein cleavage in rat ocular hypertension. Invest Ophthalmol Vis Sci 2002; 43(4): 1077-87.

[138] Yoneda S, Hara H, Hirata A, Fukushima M, Inomata Y, Tanihara H. Vitreous fluid levels of beta-amyloid((1-42)) and tau in patients with retinal diseases. Jpn J Ophthalmol 2005; 49(2): 106-8.

[139] Tezel G, Hernandez R, Wax MB. Immunostaining of heat shock proteins in the retina and optic nerve head of normal and glaucomatous eyes. Arch Ophthalmol 2000; 118(4): 511-8.

[140] Qing G, Duan X, Jiang Y. Heat shock protein 72 protects retinal ganglion cells in rat model of acute glaucoma. Yan Ke Xue Bao 2005; 21(3): 163-8.

[141] Ishii Y, Kwong JMK, Caprioli J. Retinal ganglion cell protection with geranylgeranylacetone, a heat shock protein inducer, in a rat glaucoma model. Invest Ophthalmol Vis Sci 2003; 44(5): 1982-92.

[142] Uchida S, Fujiki M, Nagai $Y$, Abe T, Kobayashi H Geranylgeranylacetone, a noninvasive heat shock protein inducer, induces protein kinase $\mathrm{C}$ and leads to neuroprotection against cerebral infarction in rats. Neurosci Lett 2006; 396(3): 220-4.

[143] Bringmann A, Grosche A, Pannicke T, Reichenbach A. GABA and glutamate uptake and metabolism in retinal glial (Müller) cells. Front Endocrinol (Lausanne) 2013; 2013; $4: 48$.

[144] Junier MP. What role(s) for TGFalpha in the central nervous system? Prog Neurobiol 2000; 62(5): 443-73.

[145] Liu X, Clark AF, Wordinger RJ. Expression of ciliary neurotrophic factor (CNTF) and its tripartite receptor complex by cells of the human optic nerve head. Mol Vis 2007; 13: 758-63.

[146] Gris P, Tighe A, Levin D, Sharma R, Brown A. Transcriptional regulation of scar gene expression in primary astrocytes. Glia 2007 55(11): 1145-55 
[147] Leibinger M, Müller A, Andreadaki A, Hauk TG, Kirsch M, Fischer D. Neuroprotective and axon growth-promoting effects following inflammatory stimulation on mature retinal ganglion cells in mice depend on ciliary neurotrophic factor and leukemia inhibitory factor. J Neurosci 2009; 29(45): 14334-41.

[148] Rose K, Litterscheid S, Klumpp S, Krieglstein J. Fibroblast growth factor 2 requires complex formation with ATP for neuroprotective activity. Neuroscience 2009; 164(4): 1695-700.

[149] Prokai-Tatrai K, Xin H, Nguyen V, et al. 17ß-estradiol eye drops protect the retinal ganglion cell layer and preserve visual function in an in vivo model of glaucoma. Mol Pharm 2013; 10(8): 3253-61.

[150] Marcus MW, Müskens RPHM, Ramdas WD, et al. Cholesterollowering drugs and incident open-angle glaucoma: a populationbased cohort study. PLoS ONE 2012; 7(1): e29724.

[151] Stein JD, Newman-Casey PA, Talwar N, Nan B, Richards JE, Musch DC. The relationship between statin use and open-angle glaucoma. Ophthalmology 2012; 119(10): 2074-81.

[152] Zhong L, Bradley J, Schubert W, et al. Erythropoietin promotes survival of retinal ganglion cells in DBA/2J glaucoma mice. Invest Ophthalmol Vis Sci 2007; 48(3): 1212-8.

[153] Tsai JC, Wu L, Worgul B, Forbes M, Cao J. Intravitreal administration of erythropoietin and preservation of retinal ganglion cells in an experimental rat model of glaucoma. Curr Eye Res 2005; 30(11): 1025-31.

[154] Bertrand J, Winton MJ, Rodriguez-Hernandez N, Campenot RB, McKerracher L. Application of Rho antagonist to neuronal cell bodies promotes neurite growth in compartmented cultures and regeneration of retinal ganglion cell axons in the optic nerve of adult rats. J Neurosci 2005; 25(5): 1113-21.

[155] Lehmann M, Fournier A, Selles-Navarro I, et al. Inactivation of Rho signaling pathway promotes CNS axon regeneration. J Neurosci 1999; 19(17): 7537-47.

[156] Sengottuvel V, Leibinger M, Pfreimer M, Andreadaki A, Fischer D. Taxol facilitates axon regeneration in the mature CNS. J Neurosci 2011; 31(7): 2688-99.

[157] Leibinger M, Andreadaki A, Fischer D. Role of mTOR in neuroprotection and axon regeneration after inflammatory stimulation. Neurobiol Dis 2012; 46(2): 314-24.
[158] Jo SA, Wang E, Benowitz LI. Ciliary neurotrophic factor is an axogenesis factor for retinal ganglion cells. Neuroscience 1999; 89(2): 579-91.

[159] Fischer D, He Z, Benowitz LI. Counteracting the Nogo receptor enhances optic nerve regeneration if retinal ganglion cells are in an active growth state. J Neurosci 2004; 24(7): 1646-51.

[160] Su Y, Wang F, Teng Y, Zhao S-G, Cui H, Pan S-H. Axonal regeneration of optic nerve after crush in Nogo66 receptor knockout mice. Neurosci Lett 2009; 460(3): 223-6.

[161] Fischer D, Pavlidis M, Thanos S. Cataractogenic lens injury prevents traumatic ganglion cell death and promotes axona regeneration both in vivo and in culture. Invest Ophthalmol Vis Sci 2000; 41(12): 3943-54.

[162] Mansour-Robaey S, Clarke DB, Wang YC, Bray GM, Aguayo AJ. Effects of ocular injury and administration of brain-derived neurotrophic factor on survival and regrowth of axotomized retinal ganglion cells. Proc Natl Acad Sci USA 1994; 91(5): 1632-6.

[163] Johnson TV, Bull ND, Martin KR. Neurotrophic factor delivery as a protective treatment for glaucoma. Exp Eye Res 2011; 93(2): 196-203.

[164] Johnson TV, Bull ND, Hunt DP, Marina N, Tomarev SI, Martin KR. Neuroprotective effects of intravitreal mesenchymal stem cel transplantation in experimental glaucoma. Invest Ophthalmol Vis Sci 2010; 51(4): 2051-9.

[165] Li N, Li X-R, Yuan J-Q. Effects of bone-marrow mesenchymal stem cells transplanted into vitreous cavity of rat injured by ischemia/reperfusion. Graefes Arch Clin Exp Ophthalmol 2009; 247(4): 503-14.

[166] Ng TK, Fortino VR, Pelaez D, Cheung HS. Progress of mesenchymal stem cell therapy for neural and retinal diseases. World J Stem Cells 2014; 6(2): 111-9.

[167] Yu S, Tanabe T, Dezawa M, Ishikawa H, Yoshimura N. Effects of bone marrow stromal cell injection in an experimental glaucoma model. Biochem Biophys Res Commun 2006; 344(4): 1071-9.

[168] Zwart I, Hill AJ, Al-Allaf $\mathrm{F}$, et al. Umbilical cord blood mesenchymal stromal cells are neuroprotective and promote regeneration in a rat optic tract model. Exp Neurol 2009; 216(2): $439-48$.

(C) M. Kolko; Licensee Bentham Open

This is an open access article licensed under the terms of the Creative Commons Attribution Non-Commercial License (http://creativecommons.org/licenses/by-nc/3.0/) which permits unrestricted, non-commercial use, distribution and reproduction in any medium, provided the work is properly cited. 